\title{
PENGARUH MEMPELAJARI BAHASA ASING TERHADAP PERKEMBANGAN OTAK ANAK
}

\section{FURQANUL HAKIM ${ }^{1)}$, SARASWATI HAYLIAN CHIANI}

\section{${ }^{1)}$ STKIP Paracendekia NW Sumbawa, ${ }^{2)}$ STIKES Grya Husada Sumbawa Besar}

\author{
e-mail : ${ }^{1)}$ furqanul_hakim@yahoo.co.id, ${ }^{2)}$ saraswatichiani@gmail.com
}

\begin{abstract}
ABSTRAK
Intelegensi anak-anak menunjukkan bagaimana kita merangsang otak mereka. Saat ini, semua orang tua secara aktif mencari stimulus terbaik untuk pertumbuhan otak anak-anak mereka. Tetapi sebagian besar orang tua masih menggunakan metode tradisional dalam merangsang otak anak-anak mereka. Misalnya, orang tua biasanya menggunakan metode instan dengan memberi anak-anak mereka beberapa obat penambah otak. Beberapa ahli percaya bahwa metode ini bukan metode yang efektif untuk digunakan.

Penelitian ini bertujuan untuk mengetahui korelasi belajar bahasa asing dengan pertumbuhan otak anak-anak, dan untuk mengetahui manfaat pembelajaran bahasa asing bagi pertumbuhan otak anak-anak

Penelitian ini dilaksakan di lembaga kursus yang bernama 24 English College Bima NTB, dengan metode observasi langsung dan mengadakan wawancara berdasarkan daftar pertanyaan /angket kepada responden yang ditentukan secara random sampling techinique, kemudian hasil penelitian dianalisis secara kualitatif dan ditunjang dengan reference (buku, media cetak maaupun elektronik yang berkaitan dengan permasalahan).

Hasil penelitian menujukkan bahwa : (1). Dengan mempelajari bahasa asing seperti Inggris, Spanyol, Prancis, dll. Dapat merangsang pertumbuhan otak anak-anak secara efektif, dan kecerdasan terhadap anak tergantung pula pada jenis stimulus apa yang mereka dapatkan. (2). Manfaat penguasaan bahasa asing adalah (a) itu memaksimalkan kinerja otak anak-anak, (b) Anak-anak dengan kemampuan bahasa asing yang baik memiliki kecerdasan dan kreativitas yang tinggi, (c) dapat menurunkan pikun dimensi, (d). memiliki fleksibilitas kognitif yang lebih baik, (e). menunda penyakit Alzheimer, (f). Anak-anak mampu memecahkan masalah jika mengasai bahasa asing, (g). Pengambil keputusan yang baik .Orang yang berpikir dalam bahasa lain ternyata cenderung membuat keputusan yang rasional
\end{abstract}

Kata kunci : Pengaruh mempelajari bahasa asing, perkembangan otak anak

\section{ABSTRACT}

Children's intelligence shows how we stimulate their brains. At present, all parents are actively looking for the best stimulus for their children's brain growth. But most parents still use traditional methods in stimulating the brains of their children. For example, parents usually use the instant method by giving their children some brain enhancing drugs. Some experts believe that this method is not an effective method to be used.

This study aims to determine the correlation of learning foreign languages with the growth of children's brains, and to find out the benefits of learning foreign languages for the growth of children's brains

This research is conducted at a course called 24 English College Bima NTB, with direct observation methods and conducted interviews based on questionnaires to respondents who are determined by techinique random sampling, then the results of the study are analyzed qualitatively and supported by references (books, printed media or electronically related to the problem).

The results of the study show that: (1). By learning foreign languages such as English, Spanish, French, etc. Can stimulate children's brain growth effectively, and intelligence on children also depends on what type of stimulus they get. (2). The benefits of mastering a foreign language are (a) it maximizes children's brain performance, (b) Children with good foreign language skills have high intelligence and creativity, (c) can decrease senile dimensions, (d). have better cognitive flexibility, (e). delay Alzheimer's disease, $(f)$. Children are able to solve problems if they use a foreign language, $(g)$. Good decision makers. People who think in other languages tend to make rational decisions 


\section{PENDAHULUAN}

Intelegensi anak-anak menunjukkan bagaimana kita merangsang otak mereka. Saat ini, semua orang tua secara aktif mencari stimulus terbaik untuk pertumbuhan otak anak-anak mereka. Namun sebagian besar orang tua masih menggunakan metode tradisional dalam merangsang otak anak-anak mereka. Misalnya, orang tua biasanya menggunakan metode instan dengan memberi anak-anak mereka beberapa obat penambah otak. Beberapa ahli percaya bahwa metode ini bukan metode yang efektif untuk digunakan.

Pam Schiller (2005: 108) menyatakan bahwa dari usia empat hingga delapan tahun, otak manusia mulai mendefinisikan neuron dari setiap bunyi bahasa ibu mereka. Neuron terhubung dan memberdayakan satu sama lain. Jika mereka mendengarkan lebih dari satu bahasa, maka itu merangsang pertumbuhan neuron di otak manusia. Semakin banyak bahasa yang mereka dengarkan semakin cepat otak mereka tumbuh.

Kecerdasan seorang anak sangatlah bergantung pada bagaimana hubungan timbal-balik antara anak dengan lingkungan, pengalaman-pengalaman awal anak, serta interaksi-interaksi awal yang pernah di dialami oleh anak itu sendiri. Carnegie dalam Uce (2017: 81) menyebutkan bahwa perkembangan otak anak dipengaruhi oleh lingkungan dari yang diketahui sebelumnya. Oleh karena itu semua orang tua berusaha keras untuk mencari metode-metode terbaik untuk membangun perkembangan otak anak meskipun terkadang metode-metode yang digunakan saat ini masih terdapat banyak kelemahan-kelemahan. Orang tua sering kali melakukan hal-hal yang justru tidak baik untuk perkembangan otak dan mental anak. Sebagai contoh banyak orang tua yang cenderung memanjakan anak-anak mereka dengan pembelaan yang berlebihan atau terkadang tidak masuk akal. Misalnya orang tua memarahi meja, kursi, dan benda-benda mati lainya ketika anak mereka menangis karena menyenggol benda-benda tersebut. Padahal cara tersebut bisa berdampak negatif terhadap perkembangan otak anak. Anak cenderung menjadi malas dan tidak memiliki motivasi yang tinggi karena sudah terbiasa dimanjakan.

Selain itu kepercayaan yang berlebihan terhadap iklan-iklan produk kimia yang dipercaya mampu menjadi suplemen otak yang efektif untuk perkembangan otak anak. Jika merujuk kepada arti dari kata kimia itu sendiri, tentu hal tersebut tidak lepas dari efek samping yang secara umum diketahui sering kali berbahaya atau bahkan menjadi fatal jika dikonsumsi oleh anak. Sebagai contoh adanya anak yang menjadi cacat mental karena mengkonsumsi suplemen otak yang terlalu berlebihan. Kebiasaan mengkonsumsi suplemen ini menjadi kebiasaan yang terus berkembang dan menjamur. Hal tersebut dikarenakan kehidupan masyarakat di era yang semua serba instan.

Berawal dari fenomena di atas, sejumlah ahli mencoba meniliti secara mendalam mengenai pola terbaik yang dapat digunakan sebagai metode yang secara efektif mampu membangun kemampuan otak anak. Seiring berjalannya waktu, masyarakat semakin mempercayai hal-hal yang tidak berbau instan. Mereka mulai percaya bahwa perkembangan otak anak sangat ditentukan oleh pola lingkungan sekitar dan kebiasaan yang dilakukan oleh anak dan lingkungan sekitar.

Salah satu penelitian yang pernah dilakukan oleh Porter (2004:36) menyimpulkan bahwa saraf-saraf dalam otak yang berkaitan dengan fungsi berbahasa adalah daerah broca, wernicke, dan daerah korteks atau daerah moorsuplementer. Daerah-daerah otak teresebut merupakan daerah vital yang terdapat pada otak manusia. Ketiganya sangat berkaitan erat dengan cara kerja otak dalam merespon bahasa atau ujaran yang didengar. Ini berarti perkembangan otak anak dapat juga ditentukan oleh jumlah bahasa yang di dengar. Semakin banyak jumlah bahasa yang didengarkan maka semakin sering juga otak bekerja atau berlatih. Apabila otak sering diasah atau dilatih, maka perkembangan otak yang optimal dapat dicapai. Karena perkembangan otak juga ditentukan oleh sejauh mana otak bekerja atau sejauh mana otak manusia digunakan.

Cara kerja otak manusia sangat ditentukan dengan rangsangan-rangsangan yang diterima oleh otak. Sebagaimana yang dikemukan oleh Snell (2005:25) mengenai pengertian dari neuron dalam otak. Dijelaskan bahwa neuron adalah sel otak yang dapat dirangsang dengan stimulus tertentu. Dalam otak manusia terdapat 100 milyar neuron yang masing-masing terhubungkan satu sama lain. Penemuan ini mencoba menerangkan bahwa otak manusia akan dapat berkembang secara optimal apabila diberikan rangasangan-rangsangan yang mampu melatih otak. Salah satu rangsangan yang dapat digunakan adalah mengenalkan bahasa asing kepada anak-anak di usia dini.

\section{Perumusan Masalah}

Dari uraian di atas diajukan permasalahan adalah : 1). Apakah belajar bahasa asing berkorelasi dengan pertumbuhan otak anak-anak, 2). Apa manfaat belajar bahasa asing bagi pertumbuhan otak anak-anak 


\section{Tujuan Penelitian}

Tujuan penelitian ini adalah untuk mengetahui 1). korelasi belajar bahasa asing dengan pertumbuhan otak anak-anak, 2). manfaat pembelajaran bahasa asing bagi pertumbuhan otak anak-anak

\section{METODE PENELITIAN}

Penelitian ini dilaksakan di lembaga kursus yang bernama 24 English College Bima NTB, dengan metode observasi langsung dan mengadakan wawancara berdasarkan daftar pertanyaan /angket kepada responden yang ditentukan secara random sampling techinique, kemudian hasil penelitian dianalisis secara kualitatif dan ditunjang dengan reference (buku, media cetak maaupun elektronik yang berkaitan dengan permasalahan).

\section{HASIL PEMBAHASAN}

\section{Korelasi Belajar Bahasa Asing dengan Pertumbuhan Otak Anak}

Chamidah (2009:1) mengemukakan bahwa pertumbuhan dan perkembangan mengalami peningkatan yang pesat pada usia dini, yaitu dari 0 sampai 5 tahun. Pam Schiller (2005: 108) menambahkan bahwa antara usia empat sampai 8 bulan otak manuasia akan menetapkan sebuah neuronuntuk setiap suara dalam bahasa ibu seorang anak. Neuron-neuron ini disambungkan dan diperkuat seiring mulainya seorang anak menghubungkan suara dan pembicaraan yang mereka dengar. Jika jumlah bahasa yang didengarkan lebih dari satu, maka otak juga akan menetapkan neuron-neuron bagi bahasa-bahasa yang didengarkan. Ini berarti pengenalan bahasa asing dianggap efektif untuk membantu perkembangan otak anak.

Penjelasan di atas menunjukan bahwa bahasa asing seperti bahasa Inggris, Spanyol, Prancis, dll.dapat dijadikan alat untuk merangsang perkembangan otak anak. Beberapa sumber menemukan ada tiga hal penting yang dapat diperoleh dar ipenggunaan bahasa asing. (1) dapat memaksimalkan -kerja otak sehingga membentuk sel-selotak yang mampu merangsang intelegensi anak menjadi lebih baik. (2) anak yang mahir berbahasa asing memiliki intelegency yang tinggi serta lebih kreatif. (3) pengenalan bahasa asing juga ditengarai mampu mengurangi dimensi kepikunan. Selain itu peneliti juga menemukan kelemahan metode ini.Andini (2017: 2) juga menjelaskan bahwa otak orang yang mempelajari dua bahasa atau lebih dengan orang yang hanya mempelajari satu bahasa memiliki perbedaan yang berarti. Bahasa melibatkan fungsi otak kiri, yakni otak yang dominan dan analitis dalam proses logis dan juga belahan kanan yang aktif dalam proses emosional dan sosial.

Menurut Porter (2004:36), bahwa saraf-saraf dalam otak yang berkaitan dengan fungsi berbahasa adalah daerah broca, wernicke, dan daerah korteks atau daerah moorsuplementer. Daerah-daerah otak teresebut merupakan daerah vital yang terdapat pada otak manusia. Ketiganya sangat berkaitan erat dengan cara kerja otak dalam merespon bahasa atau ujaran yang didengar. Ini berarti perkembangan otak anak dapat juga ditentukan oleh jumlah bahasa yang di dengar. Semakin banyak jumlah bahasa yang didengarkan maka semakin sering juga otak bekerja atau berlatih. Apabila otak sering diasah atau dilatih, maka perkembangan otak yang optimal dapat dicapai. Karena perkembangan otak juga ditentukan oleh sejauh mana otak bekerja atau sejauh mana otak manusia digunakan.

Cara kerja otak manusia sangat ditentukan dengan rangsangan-rangsangan yang diterima oleh otak. Sebagaimana yang dikemukan oleh Snell (2005:25) mengenai pengertian dari neuron dalam otak. Dijelaskan bahwa neuron adalah sel otak yang dapat dirangsang dengan stimulus tertentu. Dalam otak manusia terdapat 100 milyar neuron yang masing-masing terhubungkan satu sama lain. Penemuan ini mencoba menerangkan bahwa otak manusia akan dapat berkembang secara optimal apabila diberikan rangasangan-rangsangan yang mampu melatih otak. Salah satu rangsangan yang dapat digunakan adalah mengenalkan bahasa asing kepada anak-anak di usia dini.

Adapun hasil temuan yang diporoleh adalah sebagai berikut:

1. Hampir semua siswa yang dijadikan sebagai sample pada umumnya memiliki peringkat kelas yang cukup baik di sekolah mereka masing-masing. Rata-rata siswa mendapat peringkat sepuluh besar. Ada juga diantara mereka yang cukup konsisten memperoleh peringkat tiga besar. Bahkan ada yang dari sekolah dasar hingga menengah atas mendapat peringkat satu. Selain itu peneliti juga menemukan beberapa siswa terpilih mengikuti kelas akselerasi setelah melewati test yang cukup berat. Salah satu test yang diikuti adalah tes IQ dan menjadi faktor penentu utama untuk kelulusan siswa yang akan mengikuti kelas akselerasi. Dari keterangan yang dijelaskan oleh siswa, jumlah siswa yang saat mengikuti test cukup 
banyak. Namun yang lulus dan terima sebagai siswa akselerasi hanya sedikit. setelah mencoba mencocokan antara keterangan dan data di sekolah, peneliti menemukan $80 \%$ siswa yang masuk ke kelas program akselerasi berasal dari siswa yang pernah atau masih mengikuti kegiatan kursus bahasa asing khususnya bahasa Inggris. Hasil tes IQ yang diperoleh mereka cukup jauh lebih menonjol dari temanteman mereka yang tidak atau belum pernah mengikuti kursus bahasa asing khususnya bahasa Inggris. Selain itu tidak sedikit dari siswa juga memiliki prestasi yang cukup baik. Mereka mengikuti berbagai bidang lomba seperti cerdas cermat, olimpiade bidang studi, olah raga dan lain-lain. Baik di tingkat regional, lokal, maupun nasional. Hal ini dilihat dari jumlah piagam penghargaan yang dimiliki oleh para siswa Hasil temuan ini menguatkan anggapan para ahli mengenai perkembangan otak anak dapat ditentukan oleh sejauh mana seorang anak mengenal atau menguasai bahasa asing. Semakin baik seorang anak menguasai bahasa asing maka semakin baik pula perkembangan otak anak. Hal ini dibuktikan dengan siswa yang memiliki nilai IQ tertinggi adalah siswa yang tingkat kemampuan berbahasa asingnya paling baik diantar yang lain. Dari penjabaran ini dapat disimpulkan bahwa anak yang mengenal dan mahir berbahasa asing cenderung memiliki tingkat intelegensi yang baik pula.

2. Sebagian besar anak-anak yang mengenal dan mahir berbahasa asing cenderung memiliki tingkat kreativitas yang cukup tinggi. Hal ini dapat dilihat dari kegiatan extrakurikuler yang diikuti oleh para siswa. Sebagian besar siswa yang mengenal dan menguasai bahasa asing cenderung aktif mengikuti berbagai kegiatan extrakurikuler. Salah satu contoh kegiatan yang diikuti adalah majalah dinding sekolah. Dalam kegiatan tersebut siswa berperan sebagai penulis, mereka menulis dan mencari sendiri bahan majalah dinding mereka. Jika membandingkan hasil tulisan mereka dengan teman-teman yang lain, guruguru mereka memberi penilaian bahwa mereka memiliki kualitas tulisan yang lebih baik dari temanteman yang tidak menguasai bahasa asing. Jika ditarik sebuah benang merah salah satu faktor yang membuat mereka memiliki tulisan yang lebih baik adalah sumber referensi mereka dimungkinkan jauh lebih banyak dari teman-teman lain. Hal ini dikarenakan penguasaan bahasa asing akan menunjang mereka untuk memperoleh referensi yang lebih dari sumber-sumber yang menggunakan bahasa asing. Sedankan teman-teman yang tidak mengenal atau menguasai bahasa asing cenderung memiliki referensi yang terbatas. Selain kegiatan majalah dinding sekolah, beberapa siswa juga cukup aktif dalam kegiatan extrakurikuler bidang IT. Siswa yang memiliki kemampuan berbahasa asing cenderung lebih kreatif dalam menggunakan aplikasi-aplikasi IT. Penguasaan bahasa asing menjadi sangat penting dikarenakan aplikasi-aplikasi yang terdapat dalam alat-alat IT pada umumnya menggunakan bahasa asing. Salah satu contoh instruksi cara penggunaan alat dituliskan dalam bahasa asing. Salah satu guru pembimbing yang peneliti wawancarai menjelaskan, siswa yang memiliki kemampuan berbahasa asing cenderung lebih mudah diarahkkan dan dibimbing dari pada siswa yang tidak mahir berbahasa asing. Kegiatan extrakurikuler di bidang music juga menjadi salah satu pilihan yang diikuti oleh para siswa. Siswa yang memiliki kemampuan berbahasa asing dinilain memiliki kreatifitas yang lebih dalam bermusik. Sebagai contoh, siswa yang berperan sebagai vocalist memiliki kemampuan bernyanyi yang cukup baik. Hal ini dimungkinkan karena perbendaharaaan lagu mereka cukup banyak. Selain lagu-lagu dalam negeri, mereka bisa dengan mudah meniru atau belajar dari lagu-lagu mancanegara yang secara kualitas tentunya baik. Dengan demikian dapat disimpulkan bahwa kemampuan berbahasa asing juga menjadi penunjang yang cukup baik untuk membentuk anak menjadi lebih kreatif. Jika anak menjadi lebih kreatif, hal ini dapat memperkuat anggapan mengenai pengaruh bahasa asing terhadap perkembangan otak anak cukup signifikan.

Pengenalan bahasa asing merupakan salah satu betuk rangsangan positif bagi otak. Dikatakan positif karena dengan mengenalkan bahasa asing sebagai stimulus otak maka neuron atau sel otak yang merespon dan bekerja. Dan dalam prosesnya sel-sel otak yang menerima rangsangan bahasa asing akan mengaitkan diri dengan sel-sel lain dalam otak. Apabila sel-sel lain ikut bekerja dan diasah maka secara otomatis kinerja otak akan semakin baik. Hal ini didukung oleh teori kognitif yang dikemukakan oleh Piaget dalam Handayani (2016: 179) bahwa bahasa itu bukanlah suatu ciri alamiah yang terpisah, melainkan salah satu di antara beberapa kemampuan yang berasal dari kematangan kognitif.

Sebuah penelitian yang dilakukan oleh para ahli neurosains di Eropa yang dipaparkan pada seminar di University College London pada tahun 2004, bahwa proses pembelajaran bahas asing dapat mengubah anatomi otak. Mereka menemukan bahwa terdapat area dalam otak yang disebut grey area yaitu bagian otak yang mengolah informasi. Dalam prosesnya area ini akan berkembang seperti layaknya pembentukan otot dalam sebuah latihan badan. Dengan kata lain otak diajak berolahraga dengan bahasa asing. Orang yang menguasai lebih dari satu bahasa detemukan juga memiliki banyak sel-sel kelabu sebagai pengolah informasi. Ini berarti bahwa sel-sel otak akan berkembang jika terus berolah raga. Semakin sering otak dilatih maka perkembangan otak akan semakin optimal. Selain itu tim peneliti juga mengungkap perbandingan jumlah sel kelabu yang dimiliki oleh orang bilingual lebih banyak daripada yang monolingual. 
Raefean (2005:25) juga mengiyakan penemuan yang dipaparkan oleh tim peniliti di atas, bahwa derajat korelasi antara penguasaan bahasa asing dengan jumlah sel-sel kelabu otak juga berhubungan dengan kefasihan seseorang. Menurutnya, sel-sel kelabu yang terdapat pada permukaan otak adalah sel-sel yang memiliki kemampuan fungsi luhur seperti berpikir, mengingat, berbicara, dan sebagainya. Sedangkan jaringan yang terdapat di bagian dalam otak sebagian besar hanya terdiri dari lemak yang berfungsi menyangga sel-sel kelabu. Hal ini menunjukan bahwa asupan bahasa asing mampu membentuk sel-sel kelabu baru pada otak manuasia. Orang dewasa yang belajar bahasa asing juga akan mengalami penambahan sel-sel kelabunya, tetapi perkembangannya tak akan sepesat bila ia belajar bahasa asing sejak kecil. Temun empirik ini membenarkan anggapan yang menyarankan orang tua untuk mengenalkan bahasa asing kepada anak-anaknya sejak dini.

Menurut peneliti sebenarnya pada tahap pengenalan tidak menuntut si anak untuk menguasai bahasa asing yang diajarkan. Jadi orang tua tidak perlu merasa kesulitan di tahap ini. Kita cukup menggunakan caracara yang sederhana misalnya mengenalkan mereka beberapa kata yang dekat dengan dunia mereka. Sebagai contoh jika anak sedang menyukai menggambar, kita bisa mengenalkan mereka kata-kata yang berkaitan dengan warna, atau objek-objek yang sering mereka gambar. Pola ini sebaikanya dilakukan secara terus menerus. Semakin sering si anak mendengarkan kata-kata dari bahasa asing, semakin terlatih pula otak anak. Apabila otak anak sudah sering dilatih maka pembentukan sel-sel kelabu yang dimaksud ole Michelli akan tercapai. Salah satu bukti keberhasilan yang akan dijumpai adalah si anak bisa saja menguasai kata yang kita kenalkan tadi karena terbiasanya mereka dengan kata-kata tersebut. Keunggulan ini juga ditemukan terdapat kendala yang menghambat penggunaan cara ini. Adapun hal yang mampu menjadi penghambat adalah sikap sebagian orang tua yang acuh terhadap penggunaan bahasa asing. Mereka cenderung berlebihan menggunakan bahasa ibu dalam kehidupan sehari-hari. Terkadang pengenalan terhadap hal-hal baru termasuk pengenalan bahasa asing masih enggan dilakukan karena dianggap tidak penting atau bahkan dianggap tabu.

Pada dasarnya anak-anak sangat tertarik terhadap media audio visual. Di jaman yang serba digital sekarang ini media tersebut sangat mudah dijumpai. Hampir sebagian besar masyarakat kita dekat dengan media tersebut. Sebagai bukti, kita bisa melihat sebagian besar dari masyarakat sudah memiliki stasiun TV, komputer, smartphone, dll. Kondisi ini sangat menunjang dalam mengaplikasikan metode pengenalan bahasa asing untuk membantu perkembangan otak anak.

Hal yang mungkin bisa dilakukan adalah orang tua bisa mencoba mengenalkan alat-alat tersebut kepada anak mereka. Pengenalan bahasa asing dapat dicapai dengan cara mengatur aplikasi-aplikasi pada media-media tersebut kedalam fornat bahasa asing. Meskipun sederhana cara ini sangat efektif karena anakanak menyukasi media-media semacam ini. Tidak jarang kita jumpai anak-anak yang tidak bisa jauh dari media tersebut. Semakin dekat dan disukainya pola ini maka semakin efektif pola pengenalan bahasa asing terhadap anak. Kondisi ini dapat kita manfaatkan dengan menyelipkan nilai pendidikan didalamnya dengan tujuan mengasah otak anak sehingga kita dapat membantu perkembangan otak anak kita. Pada poin yang kedua ini juga ditemukan kelemahan. Tidak semua masyarakat kita memiliki media-media tersebut. Selain itu masih ada orang tua yang enggan menfasilitasi anak-anak mereka dengan alat-alat semacam ini. Hal ini dikarenakan kekhawatiran orang tua terhadap penyalahgunaan media-media tersebut. Sebagai contoh, tidak sedikit kita temui anak yang menggunakan media HP atau Komputer untuk hal-hal yang negative seperti menonton video porno atau menghabiskan waktu mereka dengan hal-hal negative lainnya.

\section{Manfaat Pembelasajan Bahasa Asing Bagi Perkembangan Otak Anak}

Bahasa adalah salah satu unsur kebudayaan. Oleh karena itu bahasa tidak dapat dipisahkan dengan kehidupan manusia. Bahasa digunakan sebagai alat komunikasi dalam kehidupan manusia. Tanpa bahasa manusia tidak dapat menyampaikan serta menerima pikiran atau pesan antara satu dengan lainya. Dengan memperhatikan hal tersebut, maka pola yang dapat digunakan untuk memperkanalkan atau mengajarkan bahasa asing adalah dengan menempatkan anak-anak kita di lingkungan yang sering atau terbiasa menggunakan bahasa asing. Jika pola ini yang digunakan, maka pola ini dirasa tidak begitu sulit. Hal ini dikarenakan ketersedian lingkungan berbahasa asing yg cukup. Kita bisa menjumpai banyak lembagalembaga khususnya di kota besar yang menyediakan pelatihan atau kursus bahasa asing. Yang paling populer adalah hampir semua daerah terdapat banyak kursus bahasa asing seperti bahasa Inggris.

Fenomena menjamurnya pertumbuhan lembaga kursus bahasa inggris ini menjadi fasilitas penunjang yang sangat baik untuk mengenalkan atau mengajarkan bahasa asing kepada anak-anak itu sehingga orang tua mampu membangun perkembangan otak anak secara optimal. Selain ketersediaan lembaga-lembaga pelatihan dan kursus, sebagai salah satu negara tujuan wisata dunia masyarakat akan semakin terbantu 
dengan kondisi tersebut. Orang tua bisa saja membuat program rutin untuk mengunjungi tempat-tempat wisata yang biasa dikunjungi oleh para turis mancanegara sekedar untuk melatih kemampuan berbahasa asing anak dengan para turis. Atau paling tidak anak-anak bisa diajak sekedar mendengarkan bagaiamana para turis berinteraksi. Dengan demikian metode pengenalan bahasa asing untuk mengembangkan otak anak sangat mungkin dilakukan bagi masyarakat kita.

Menurut Home Lifestyle Health Concerns Kompas.com - 17/06/2014 ada 7 (tujuh) manfaat menguasai bahasa asing bagi otak yaitu :

1. Kelenturan kognitif orang dewasa yang bisa berbicara dua bahasa sejak masih anak-anak diketahui memiliki fleksibilitas kognitif yang lebih baik. Ini berarti, mereka lebih mampu beradaptasi di lingkungan baru atau yang tak terduga.

2. Otak lebih tajam .Manfaat ini juga dirasakan oleh mereka yang belajar bahasa asing pada usia dewasa. Mereka yang menguasai dua atau lebih bahasa asing memiliki kemampuan yang lebih baik dalam membaca dan juga kecerdasan.

3. Melihat kata secara berbeda Orang yang menguasai dua bahasa akan memproses beberapa kata dengan lebih cepat, terutama dua kata yang punya arti sama dalam dua bahasa itu.

4. Menunda penyakit Alzheimer .Walau tidak membuat kita imun terhadap penyakit Alzheimer, tetapi orang yang bilingual ternyata penyakitnya lebih lama muncul dibanding orang yang bicara satu bahasa.

5. Kemampuan memecahkan masalah Anak-anak yang menguasai dua bahasa juga memiliki hasil tes memecahkan masalah yang lebih baik. Dalam studi yang melibatkan 121 anak ini, mereka diminta mengerjakan pengulangan angka, soal matematika, serta membuat pola balok berwarna.

6. Otak lebih cepat saat berpindah Anak-anak yang mempelajari lebih dari satu bahasa ternyata lebih cepat mengganti atau beralih perhatiannya saat tugas-tugas diberikan.

7. Pengambil keputusan yang baik Orang yang berpikir dalam bahasa lain ternyata cenderung membuat keputusan yang rasional. Orang yang melakukan proses berpikir dalam bahasa lain juga tidak terlalu menggunakan emosi saat membuat keputusan

\section{PENUTUP}

\section{Simpulan}

Hasil penelitian menunjukkan bahwa :

1. Dengan mempelajari bahasa asing seperti Inggris, Spanyol, Prancis, dll. Dapat merangsang pertumbuhan otak anak-anak secara efektif, dan kecerdasan terhadap anak tergantung pula pada jenis stimulus apa yang mereka dapatkan. Mempelajari bahasa asing di masa keemasan mereka bisa menjadi salah satu stimulus terbaik

2. Manfaat penguasaan bahasa asing; (a) itu memaksimalkan kinerja otak anak-anak, (b) Anak-anak dengan kemampuan bahasa asing yang baik memiliki kecerdasan dan kreativitas yang tinggi, (c) dapat menurunkan pikun dimensi, (d). memiliki fleksibilitas kognitif yang lebih baik, (f). menunda penyakit Alzheimer, (g). Anak-anak mampu memecahkan masalah jika mengasai bahasa asing, (h). Pengambil keputusan yang baik . Orang yang berpikir dalam bahasa lain ternyata cenderung membuat keputusan yang rasional

\section{DAFTAR PUSTAKA}

Andini, Widya, Citra.2017. Bagaimana Belajat Bahasa Asing Bisa Meningkatkan Fungsi Otak?. https://www.google.com/amp/s/hellosehat.com/hidup-sehat/fakta-unik/belajar-bahasa-meningkatkanfungsi-otak/amp/

Anonim, 2005. Tabloid Mother and Baby. Edisi Selasa, 4 Januari 2005

Chamidah, Atien, Nur. 2009. Pentingnya Stimulasi Dini Bagi Tumbuh Kembang Otak Anak. Yogyakarta: Talkshow "Tumbuh Kembang dan Kesehatan Anak"

Handayani, Sri. 2016. Urgensi Pengenalan Bahasa Inggris Pada Anak Usia Dini Dipadang Dari Persepktif Psikolinguistik. Jurnal: Widya Wacana Vol. 11 Nomor 2.

Kompas.com dengan judul "7 Manfaat Menguasai Bahasa Asing bagi Otak", https://lifestyle.kompas.com/read/2014/06/17/1535246/7.Manfaat.Menguasai.Bahasa.Asing.bagi.Otak

Raefan, P. (2005). Atlas Anatomi, Jakarta. Jakarta: Djambantan.

Schiller, Pam. (2005). Start Smart: memompa kecerdasan sejak dini. Erlangga Kids. Surabaya

Snell, Richard. (2006). Neuroanatomy Klinik. EGC Press. Jakarta

Uce, Loeziana (2017). The Golden Age: Masa Efektif Merancang Kualitas Anak. Jurnal UIN Ar-Raniry. 